\title{
【奨励賞研究】
}

\section{視覚障害者向けタッピングゲームを用いた リズム認知の評価}

\author{
星野 隼人 \\ 筑波技術大学 保健科学部
}

\section{1. 背景と目的}

情報通信技術の発展に伴い, 視覚障害者の中で音楽ゲームを楽 しむ人が増えている. 音楽ゲームとは, 音楽に合わせて演奏したり, ステップを踏んだりといった，音を中心にプレイするゲームであり,こ れにより, 知覚の訓練や教育, 趣味に活用することができる.

音楽ゲームでは音楽と共にノーツ(音符)と呼ばれるオブジェクト の移動にあわせて, 所定の位置でキ一を正しく押せるかを競う。一方 で, 視覚障害者が通常のタッピングゲームを行うと, 音楽は聴けるが, 視覚によりノーツの動きを正確に把握することが困難であるため,う まくプレイすることができない

本研究では, ノツツの提示方法に着目し,ノーツに特殊な音を挿 入することにより，視覚障害者でも容易にタッピングゲームを楽しめる 方法について検討した. 試作したゲームでは, ノーツに「先行音」と 呼ばれる音を付加することで, 所定の位置で正しくキーを押せるかを 実験し評価を行った。

\section{2. 先行音を用いたタッピングゲーム}

リズム認知の評価のためゲームを試作した．開発にあたっては Unity を使用した. 表示例を Fig.1 に示寸. ゲームを開始すると, ノー ツが曲に合わせて上から下に降りてくる. 先行音が鳴ってから規定 の時間が経つと, ノツが判定ラインと重なる.このときスペースキー を押寸ことにより, 成功か失敗かの判定を行う. [1]などの先行研究を 参考にして, ノツツが出現し, 判定ラインに重なるまでの時間を 1 秒 に設定した. また判定ラインと重なる前後 0.15 秒, 合計 0.3 秒の時間 を成功と判定することにした。

先行音としては,「スラップ」音を採用した. スラップ音は, ノーツと 判定ラインが重なるときを基点として，それより前に鳴らすものであり， (1) 四分音符のスラップ音が 3 回鳴った後, または (2) 八分音符のス ラップ音が 2 回鳴った後、にそれぞれキーを押す仕様にした.

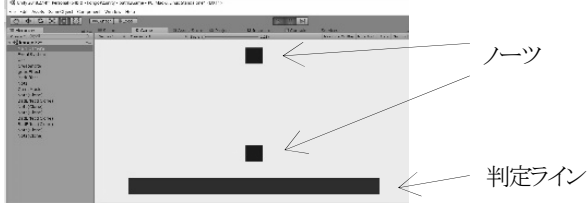

Fig.1 開発したタッピングゲーム

\section{3. 実験方法}

実験により，試作したゲームに対するリズム認識について評価し た. 実験で使用する曲には「カエルの歌」を採用した. 楽譜作成には MuseScore を使用し, 曲のテンポを120BPM とした. 実験では, 先行 音の配置場所を変えた曲を 3 パターン用意した。

それぞれの楽譜に対し,スラップ音として「ピアニシッシモ」,「ピア ノ,「フォルテ」,「フォルテシシシモ」となる 4 種類の強弱記号をもつ 曲を作成した.これにより合計 12 種類の曲を作成した.いずれの曲 に対しても, 1 つの曲に7つの先行音を配置した. 楽譜 1 に属する曲 の一例を Fig.2 に示寸.

実験はこれまでに 6 名が参加した. 内訳は弱視, 全盲がそれぞれ 3 名であった. 実験では, 最初にゲームの仕様や概要について説明 を受けた後, 12 曲をランダムにプレイし,それぞれ成功, 失敗の回数 をカウントした. 最後にプレイ終了後, 各種のアンケートに答えてもら った.

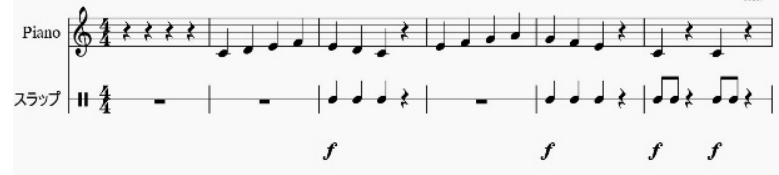

Fig.2 楽譜のパターン例

\section{4. 結果·考察とまとめ}

今回の実験により,ピアニシッシモのように相対的に弱い先行音 の場合, 成功率が著しく落ちることがわかった. 一方で, 先行音を休 符位置に設置するかどうかに関わらず, 先行音にある一定以上の強 さがある場合, または四分音符, 八分音符のタイミングが良い場合, 被験者は先行音を十分に認識できることがわかった。

被験者からは，「スラップ音があってもゲームとして楽しむことがで きた」や「先行音が出現する間隔はちようどよかった」,「先行音が曲と 重なった場合, キーを押寸タイミングを外してしまうことある」といった 意見があった. 本研究により, 規則性をもつ先行音を付加しても, 視 覚障害者は音楽ゲームのプレイが可能と考える.

\section{参考文献}

1）三輪聡哉，中村聡史, “マイクロタスク埋め込み型音楽ゲームの 提案”, エンタテインメントコンピューティング研究会，情報処 理学会, 2014-EC-34(2), pp.1-6, 2004 